\title{
Media outlets and their moguls: why concentrated individual or family ownership is bad for editorial independence
}

This article investigates the levels of owner influence in 211 different print and broadcast outlets in 32 different European media markets. Drawing on the literature from industrial organisation, it sets out reasons why we should expect greater levels of influence where ownership of individual outlets is concentrated; where it is concentrated in the hands of individuals or families; and where ownership groups own multiple outlets in the same media market. Conversely, we should expect lower levels of influence where ownership is dispersed between transnational companies. The articles uses original data on the ownership structures of these outlets, and combines it with reliable expert judgments as to the level of owner influence in each of the outlets. These hypotheses are tested and confirmed in a multilevel regression model of owner influence. The findings are relevant for policy on ownership limits in the media, and for the debate over transnational versus local control of media. (6,954 words)

Keywords: comparative research; corporations; newspaper industry; political economy 


\title{
Media outlets and their moguls: why concentrated individual or family ownership is bad for editorial
}

\author{
independence
}

\section{Introduction}

In 1981, the Thompson Organisation had to decide to whom to sell its flagship titles, the Times and Sunday Times. The group had two concerns - that the future of both papers be guaranteed, and that their independence from proprietorial influence be preserved. Editorial independence had been an issue when the Thompson Organisation initially acquired the newspapers, and remained salient, especially given the Sunday Times' free-wheeling investigative journalism (Shawcross, 1997, 122). One question for those directing the sale was whether 'youthful' and 'vigorous' Australian Rupert Murdoch could guarantee that independence. This group had to bear in mind that Murdoch's company, News Corporation and its wholly-owned subsidiary News International, was ultimately controlled by the Murdoch family, who had a stake of around $46 \%$ through their investment vehicle Cruden Investments (Stevenson, 1985). Accordingly, when the group decided to accept Murdoch's bid, it imposed several conditions, not least that the board of the newspaper have a majority of independent directors 
who would have to approve the appointment of editors (Leveson, 2011, 104$105)$.

Concerns over editorial independence of a different sort were expressed by journalists in Central and Eastern Europe during the first wave of take-overs of print and broadcast titles by transnational media companies. Reactions "displayed a mixture of hopes and concerns" (Stetka, 2012, 438). The European Federation of Journalists warned that the aggressive commercialism of these corporations risked undermining journalistic standards, presumably including editorial independence (Stetka, 2012, 439). This concern was not due to the presence of a strong individual ownership interest - a Rupert Murdoch or a Silvio Berlusconi. Rather, it was due to a fear that dispersed corporate ownership could still pose a threat to editorial independence.

Whilst the Thompson Organisation and Central and Eastern European journalists faced very different choices, they shared a common interest in protecting editorial independence. Their choices were no doubt influenced by the character of the respective parties, perhaps even their 'alarming charm' (Evans, 1983, 124). For academics and policy-makers, however, important questions exist independently of the charm or suasion exercised by individuals. Considering the following structural characteristics, which group had greater reason to be concerned about owner influence - the Thompson group, faced with a company (News Corporation) already operating in the UK market, with a single dominant individual ownership interest (Rupert Murdoch)? Or journalists in Central and Eastern Europe, faced with foreign-owned companies making 
their first foray in emerging markets, with multiple foreign owners of different types?

Strangely, the academic literature offers no easy answer to this question, despite agreement that the important question was whether or not owner influence was "due to the characteristics of individual owners and managers or to some systematic impact inherent in the different types of ownership and management" (Lacy, 1991, 38). Lack of an easy answer is not due to inattention to questions of ownership: in many instances we know who owns the media (for a given understanding of ownership), either within a single country (Noam, 2009) or across many countries (Djankov et al., 2003). Nor is it due to inattention to influences on journalism, as this is currently an active area of research (Hanitzsch and Mellado, 2011). Rather, it is due to the difficulty of collecting sufficient, and sufficiently varied, data on both influence and ownership structure. This is particularly difficult when interest lies not just in identifying a single 'type' of owner ('transnational corporation' or 'media tycoon'), but in identifying the shares of different ownership interests, and the concentration thereof. Such research requires much tedious work in analyzing annual company reports. Nevertheless, investigation in this level of detail is necessary, because it is the kind of detail with which regulators must regularly operate, as recent cases in the UK have shown (Ofcom, 2010).

This article therefore presents detailed data on the ownership structure of 211 media titles in 32 different media markets. ${ }^{1}$ This data allows us to investigate the

1 Austria, Flemish Belgium, Francophone Belgium, Bulgaria, Croatia, Cyprus, Czech Republic, Denmark, Estonia, Finland, France, Germany, Great Britain, Greece, Hungary, Ireland, Italy, Latvia, Lithuania, Malta, 
effects on owner influence of concentration of ownership, the type of ownership interests, and whether or not the ownership group as a whole owns multiple titles within the domestic market. After reviewing relevant literature, I go on to discuss the sources of my data on ownership structure, and expert judgments of owner influence. I model levels of owner influence using a multilevel regression model, before concluding and discussing the implications of these findings for regulators.

\section{Literature}

The 'problem' of owner influence is not unique to media companies. Tensions between shareholders and corporate executives are almost as well known as tensions between media owners and their editors. Because this problem is shared with other companies, I analyze owner influence over media outlets by borrowing from the literature on industrial organisation. Before I can summarize that literature, I first describe some conceptual issues relating to ownership and influence. Having clarified these concepts, I then move on to discussing the findings of the existing media studies literature on ownership and influence, before introducing the literature on industrial organisation.

Netherlands, Norway, Poland, Portugal, Romania, Russia, Serbia, Slovakia, Slovenia, Spain, Sweden, Ukraine. 


\section{What is ownership?}

The considerable literature on media ownership ${ }^{2}$ has often faced one serious problem in understanding ownership, namely a problem of aggregating ownership across multiple media outlets operating in different media. Crossownership of print and broadcast outlets makes it difficult to find a common denominator in terms of audience share or circulation. Public media make it difficult to find a common denominator in terms of revenue. This problem of aggregation masks a more fundamental problem of identifying particular ownership interests. One option is to suggest that each media outlet has a single ultimate ownership interest. This is the approach taken by Djankov et al. (2003), who proceed according to the following algorithm:

1. identify, for each media outlet, all the ownership interests (proximate owners);

2. of the proximate owners identified in the preceding step, take the proximate owner with the largest share of ownership;

3. if this ownership share is greater than $20 \%$, ask whether this proximate owner is an individual, a family, an association of employees, or the state

4. if yes, identify this owner as the ultimate owner, and stop

5. if no, return to step (2) and repeat, identifying the proximate owners of this proximate owner.

2 Here I am largely addressing the literature on media ownership 'as data' in contrast to broader normative and ideological accounts of ownership, though such accounts obviously supervene (to a greater or lesser degree) on such empirical accounts (Freedman, 2012). 
6. if the ownership share from (2) is not greater than $20 \%$, identify the ownership as widely held.

Using this method, Djankov et al. $(2003,373)$ are able to claim that media firms "nearly universally have ownership structures with large controlling shareholders and that these shareholders are either families or governments". This approach, and in particular its insistence that media are ultimately owned by an owner of a given 'type', is helpful and not overly reductive when the aim is construct aggregate national statistics about state, family, or private company ownership. However, it is less appropriate when the aim is to investigate control of particular outlets. In some cases, insistence of chasing down a single ultimate owner means going through three or four levels of proximate owners. Eventual ultimate owners can be left with a very small share of the media outlet as a result of share splits at each level of ownership. This is the case for the Bonnier family's 22.9\% ownership of Radio Nova, Finland, and for the Schneider family's $23.3 \%$ ownership of TV Danmark. ${ }^{3}$ In these cases, it is difficult to say that this ultimate owner 'owns' the relevant media outlet. It also leaves the question of the concentration of ownership unanalysed.

\section{What is owner influence?}

The influence exerted by owners on media workers (journalists, editors and managers) is one of many sources of influence. Of the six domains proposed by Hanitzsch and Mellado (2011, 406-407), owner influence falls within the domain of organizational influences, "sources of influence that emanate from multiple

3 Figures from the Djankov et al. dataset. 
levels: from within the newsroom (supervisors and higher editors) and from within the media organization (management and ownership)". This might be considered as owner influence per se. A separate domain of influence is often associated with owner influence, and in particular ownership by companies, namely the domain of economic influences ("profit expectations of media companies, advertising considerations, the needs of advertisers": Hanitzsch and Mellado (2011, 407)). To some extent these interests are also shared by journalists, editors and managers (Zaller 1999 includes audience share as a component of journalists' utility function). The concern here is not with economic influences, but rather with owner influence in its classic antagonistic relationship to editorial independence. In particular, I am interested in owner influence of the kind suggested by the examples at the beginning of this article: influence designed to shift the political and social tenor of the title's coverage. This kind of influence is easiest to identify when exercised overtly, through company memos, irate phone calls, or interference in hiring and dismissal (Bagdikian, 2004, 15-16); but this visible face of power is rarely the most consequential (Lukes, 1974), and influential owners rarely have to make their wishes known in order to have their will done. This raises the difficult issue of identifying owner influence empirically. Although a large body of work attempts to identify the consequences of owner influence for differences in output (Gaziano, 1989; DellaVigna and Kennedy, 2011), in this article I evaluate owner influence through an expert survey. Not only is inference through content analysis tricky, it is also conceptually flawed, for influence may not translate to 
differences in output where equal and opposing influences exist. Consequently, reliance on perceptual data is a necessary step.

\section{What does the literature say?}

There is a considerable literature on media ownership. However, much of this literature has examined concentration of ownership at the level of the media market, rather than concentration of ownership within a given media outlet. Even articles which do examine the ownership of specific outlets tend to ignore aspects of within-outlet ownership concentration (Djankov et al., 2003). There is scholarship on particular types of ownership. A rich vein of literature examines the consequences (particularly consequences for news and current affairs output) of ownership by media tycoons or moguls (Tunstall and Palmer, 1991; Stetka, 2012), by political parties (Hadenius 1983, Hamilton 2004, 37-70), by the state (Besley and Prat, 2006; Curran et al., 2009), and by multinational corporations (Stetka, 2012). However, much of this literature is interested in the effects of aggregate patterns of ownership on aggregate outcomes, and at least some interesting characteristics of ownership (such as the concentration of ownership within an individual outlet) cannot be aggregated to a system level. What is needed, therefore, is broader theoretical canvas which can bring together discussions of ownership concentration and discussions of different ownership types. I suggest that the literature on the industrial organisation of the media offers that broader canvas. 


\section{What does the industrial organisation literature say?}

The literature on industrial organisation offers two separate insights into the extent of owner influence over media outlets. The first insight comes from work following Berle and Means (1932), and which identifies levels of concentration of ownership as a key factor in determining owners' influence. A second insight comes from the literature on the benefits of ownership, and in particular the nonpecuniary benefits.

Berle and Means (1932) noted the increasing dispersion of stock ownership in modern corporations, and argued that this, together with the spread of nonvoting shares, had led to a lack of shareholder control over executives. Lack of control was undesirable because executives pursued policies which maximized their own income at the expense of shareholders' return on investment. Shareholding in media companies is much more concentrated than shareholding in other companies (Demsetz and Lehn, 1985). It would therefore seem that owners of media companies can exercise much more control than other owners. Insofar as that control is exercised to prevent media managers from shirking or selfdealing, this is beneficial; but insofar as that control is exercised in order to instil a particular editorial line in a media outlet, the 'problem' of media ownership is precisely the opposite of the problem identified by Berle and Means - there is too much, rather than too little control.

Bearle-Means style arguments have been repeatedly advanced in the field of the media by David Demers. Demers (1999) argues that corporate control of newspaper production in the United States, far from dampening editorial vigour, 
actually results in an increase in independent-minded journalism, as newspaper managers (i.e., editors) shirk the control of their dispersed corporate principals. Since Demers only includes 'ownership structure' as one of five dimensions of 'corporate newspaper structure', it is not possible to test directly the effects of concentration of ownership (Demers and Merskin, 2000, 115-116)). Nevertheless, we can consider concentration of ownership to act as an important factor intervening between (normally) independently-minded editors and owners who may have other interests.

In Demers' work, and indeed in most work in industrial organisation, the "standard assumption ... is that owners want the company to maximize... shareholder value. Although this assumption may be sufficient for many purposes, it is strictly speaking only an approximation of the more general idea that owners (like managers) may be expected to maximize their utility, which may depend on other factors" (Thomsen and Pedersen, 2000, 692). Certainly, for many standard financial indicators companies predominantly owned by some types of ownership interests (natural persons or families) enjoy different outcomes to companies predominantly owned by other types (institutional investors, banks) (ibid). In the media, part of an explanation for this difference derives from the amenity potential of ownership. Demsetz and Lehn (1985, 1161) define amenity potential as a 'nonpecuniary income associated with the provision of leadership and with the ability to deploy resources to suit one's personal preferences', and argue that it is particularly present in the media. Obvious instances of amenity potential include the potential to rub shoulders 
with government ministers and enjoy the exercise of power or the perception of such power (which is often exaggerated by politicians themselves: Strömbäck and Nord 2006, 157). Although Demsetz and Lehn consider explanations of concentration of ownership in terms of amenity potential to be somewhat 'speculative', if amenity potential is present in the media then it would seem to apply only to individual and/or family owners. It is unclear how a corporation could enjoy a nonpecuniary income resulting from the deployment of resources to suit personal preferences. Consequently, the known amenity potential of media ownership, and the greater relevance of such amenity potential for individual and family owners, can give us a further insight, additional to those provided by the literature on the concentration of ownership, into media firm control.

\section{Theory}

These insights can help us make predictions about levels of owner influence over media outlets. Specifically, we may model actual levels of owner influence as if they were the result of a voting game, where owners with divergent preferences over the ideal level of owner influence vote on proposals made by the management of the media outlet. The key intuition is that, just as in the BearleMeans account, dispersed shareholders find it difficult to vote down management proposals for high levels of executive remuneration, dispersed shareholders also find it difficult to agree on a significant departure from management-proposed low levels of owner influence. High levels of influence 
are possible, where owners have preferences over influence that are skewed to the high-influence end of the spectrum, or where ownership is concentrated, but absent these two features the management will get its way.

Formally, the voting game begins when management proposes a level of owner influence somewhere on the line $[0,1]$, where higher values indicate greater owner influence. This proposal might, for example, allocate the power to nominate various directors of divisions of the outlet, or propose a division of board members, or an editorial charter, or some other device. Owner interests then have to vote on this proposal, according to some decision-making rule (majority or qualified majority). Owner interests may vote the proposal down and make counter-proposals. However, if no counter-proposal is accepted (over some fixed number of rounds of counter-proposals), the policy reverts back to the policy proposed by the management. Assume that, on average, management proposals are to the left of the ideal points of individual, family, and state/political party ownership interests: i.e., they prefer lower levels of owner influence. If there are no problems of coordination between ownership interests (perhaps because there is a sole ownership interest), then the level of owner influence will be higher than the management proposal. Generally, we may say that the more dispersed ownership is, the greater the problem of coordinating on a counter-proposal, and thus the smaller the departure from the status quo, and the lower average level of owner influence.

Holding ownership concentration constant, the level of departure from the low-influence status quo will depend on the preferences of the different voting 
interests. Here, I hypothesise that, because of the amenity potential of media ownership, individual and family preferences will generally be further to the right than company preferences. If ownership interests uniformly prefer high levels of owner influence (perhaps if they are all individuals), then the eventual outcome will be far to the right of the initial management proposal. Conversely, if preferences are distributed around the management's ideal level of owner influence, then owner interests to the left of management will have an interest in voting down any proposal resulting in greater owner influence.

Differences in mean levels of owner influence between countries can be accounted for, if only minimally, by assuming that certain characteristics of the media system shift both management and ownership interests left or right by the same constant. Thus, the status quo ex ante might involve much greater owner influence in Italy than in Sweden.

We can extract one further hypothesis from the theory if we draw certain inferences from share-holdings in multiple outlets. One feature of the 'amenity potential' of media outlet ownership is that it cannot easily be transferred between countries. Silvio Berlusconi enjoyed huge political influence in Italy; but his efforts to replicate that success in France and (to a lesser extent) Spain largely failed. Consequently, owners who hold ownership interests in multiple countries are, on balance, likely to be more interested in maximizing return on investment than they are in the amenity potential of media ownership. Conversely, owners who hold multiple ownership interests in the same country are, on balance, more likely to be interested in the amenity potential of media 
ownership than they are in maximizing return by investing over a range of media markets. There is no necessary contradiction between maximizing one's return on investment and exercising influence (see Mullainathan and Shleifer, 2005). However, at least when considering sequential and separate investments, it would seem unusual if profit-maximizing owners were to seek out investment opportunities and conclude that more than one of the best opportunities lay in the same media market.

This theory could enable us to make point predictions if we knew the preferences of ownership interests directly. Unfortunately, we do not know this, and therefore must make predictions which are based on the effect of single factors increasing, holding other factors constant. The first of the factors identified had to do with the concentration of voting power. The concentration hypothesis claims that

H 1 The greater the concentration of voting power within an outlet, the greater the degree of owner influence

for the reasons related above which had to do both with co-ordination problems which exist with very dispersed voting power, and from reasons related to smaller departures from the status quo given a larger number of ownership interests. The identity hypothesis claims that

H 2 The greater the share of voting power within an outlet held by individuals and families compared to companies and, the greater the degree of owner influence 
This relates to earlier assumptions about the amenity potential of ownership being accessible only to individuals and families rather than corporate agents. To the extent that these assumptions are false, and corporate interests appreciate acting as power-brokers (as Fiat did with its ownership of La Stampa), then this hypothesis will not be born out.

The repeat-player hypotheses claim that

H 3 The greater the share of voting power held by ownership interests which have other ownership interests in the same country, the greater the degree of owner influence

H 4 The greater the share of voting power held by ownership interests which have ownership interests in other different media markets, the lower the degree of owner influence

This relates to earlier assumptions about the amenity potential of ownership being more difficult to enjoy in two countries simultaneously than the return on investment on two investments in different countries.

\section{Data and modelling choices}

This article draws on two sources of data: data concerning the ownership structure of different outlets, and expert judgments concerning the degree of ownership influence over each outlet. 


\section{Ownership structure}

Data on the ownership of the outlets in the 32 media markets in the study as of the start of 2010 was collected by searching company news sources on LexisNexis, and in particular by searching financial news services such as the Major Companies Database, ISS Proxy Research reports, and Worldscope. Where information could not be located on Lexis-Nexis, information was located either through group websites and annual reports, or through media regulators' websites. Where this was not possible, newspaper articles were resorted to. For each outlet information on up to ten owners was collected. For each owner, the name, percentage share of ownership, and type were recorded. We coded owner types as follows:

I Individual

Fam Family, including family foundations

Found Foundation

C Private Company

N/P/S Political party, state actor, or non-profit (often trades unions)

Many outlets included in the data have very complicated ownership structures. As far as possible, attempts were made to identify ultimate owners rather than proximate owners. Therefore, where a media outlet was wholly or partly owned by another company, and where that company was wholly owned by a third company or entity, the name, type, and percentage ownership of that third entity were reported. To give an example: the Irish broadcaster TV3 is $100 \%$ owned by 
a company called Tullamore Beta, which is $100 \%$ owned by a company called Tullamore Alpha, which is $100 \%$ owned by a company called Tullamore Omega, which is owned by the private equity fund Doughty Hanson (90.75\%) and Peter Ennis (9.25\%). Doughty Hanson and Peter Ennis were therefore reported as the two ultimate owners of TV3, and as a private company and an individual respectively.

As far as possible, we attempted to identify either at least six ownership interests, or at least a cumulative total of $80 \%$ of ownership in the company. On average, $88.53 \%$ of ownership was identified in the 211 outlets. For 59 outlets it was not possible to find information on $80 \%$ of ownership: in most of these cases, ownership is known to be widely dispersed through publicly traded shares. Because we are interested in corporate control rather than just corporate ownership, I calculated the Banzhaf scores for each ownership interest (Banzhaf, 1964). The Banzhaf score for a given ownership interest is the percentage of winning coalitions of ownership interests (under some decision making rule) which would cease to be winning if actor $i$ voted differently. Here, we assume that the decision-making rule is a majority rule, and that $50 \%+1$ of votes are necessary to pass motions. Where we were unable to locate information on $100 \%$ of the ownership of a media outlet, we assume that remaining ownership stakes are infinitesimally small and can be ignored; the Banzhaf index can then be calculated as if the identified ownership shares representing $100 \%$ of the voting stock.

[Figure 1 about here] 
Figure 1 shows the distribution of share-holding percentages and Banzhaf scores for the first, second, third, and remaining ranked ownership interests. Plotted circles give the mean for all values; crosses give the mean for non-zero values only. Both panels of the figure show visually the very quick drop-off in shareholding and control between the largest and all remaining owners.

We can speak more precisely about concentration of ownership by summarizing the Banzhaf scores of the different owners. Specifically, we can talk about the effective number of relevant owners, which is equal to the reciprocal of the sum of squared Banzhaf scores. The mean effective number of relevant owners is 1.62; this figure is lower for television (1.39) than it is for newspapers (1.79), and this difference is statistically significant (Welch's $t=2.61$ on 203.42 degrees of freedom, $p=0.01$ ). Differences in ownership concentration between media markets are not statistically significant $(\mathrm{F}(31,179)=1.05, \mathrm{p} \approx$ 0.4). In some media markets, outlets have on average only one effective owner (Belgium Francophone, Hungary, Lithuania, Malta), whilst in others the figure is much higher.

We can also compare differences in the types of owners by summing the different Banzhaf scores for each company according to the type of owner. For our purposes the most interesting variation is variation in the cumulative Banzhaf score of all individual owners of each media outlet, where the average across all outlets is 0.26 , which differs according to media markets $(F(31,179)=$ $2.46, \mathrm{p} \approx 0$ ). Individual shares of voting power are on average lowest in Flemish 
Belgium (0), Francophone Belgium (0) and Denmark (0), and highest in Latvia (0.6), Italy (0.72) and Ukraine (0.78).

Finally, we may examine which ownership groups are 'repeat players' at national, international, or both levels. Here we must shift the level of analysis from the individual ownership interest to the ownership group. We identify a repeat-player at international level as any group the members of which are all also present in another outlet in a different country; a repeat player at national level any group the members of which are all also present in another outlet in the same country; and 'single-shotters' and dual repeat-players as simple logical combinations of both of these. Most (113) of the outlets are single-shotters; only 16 are dual repeat-players.

\section{Owner influence}

The data on owner influence come from a 2010 survey of experts in the media systems of 32 European media markets conducted by Popescu et al. (2012). Experts were asked to indicate their agreement with a series of statements concerning the top media outlets, typically but not always the public broadcaster, the top three newspapers, and the top three commercial television stations. (In this article I ignore owner influence on the public broadcaster, since this involves a different set of considerations: Hanretty 2010). One of these statements concerned what we term owner influence. Experts were asked "how much is the political coverage in the [relevant] media outlet influenced by its owners?". Responses were on a scale from zero (low levels of influence) to ten (high 
levels). The reliability of the mean of expert judgements is high: the Steenbergen-Marks reliability coefficient (Steenbergen and Marks, 2007) is 0.93.

The average across all outlets is 6.11 , but this once again masks significant differences between media markets $(\mathrm{F}(31,179)=15.12, \mathrm{p} \approx 0)$. Owner influence is on average lowest in the Netherlands (2.01), Denmark (2.46) and Norway (3.19), and highest in Greece (8.1), Cyprus (8.62) and Malta (9.2). These country differences match normal assessments of press freedom in each of these countries.

[Table 1 about here]

\section{Other variables}

I also gathered data on the degree of concentration in the market, understood as the concentration of audience shares (press: readership) amongst different media groups, as calculated using the Herfindahl-Hirschman index of concentration. I include this in the models that follow because of the possibility that owners might be less likely to exercise influence where the market is competitive and potential competitors can easily attract readers or viewers who, for whatever reason, are dissatisfied by the type of coverage which results when owners intervene.

I also recorded whether each outlet was a print or broadcast outlet. I include this in the models that follow because of the possibility that owners in broadcast media might be less able to exercise influence due to the common requirement in European media systems that broadcast media follow norms of impartiality or 
fairness. Table 1 shows summary statistics for all of the numerical variables used in the models that follow.

\section{Modelling choices}

To account for the fact that outlets are nested within countries, I estimate a multilevel model using a linear regression model with a random country intercept.

For technical reasons, separate variables cannot be included for all ownership types, and so one type must be chosen as a reference category. Consequently, I use company ownership as a reference category; the coefficients for other types of ownership therefore represent the change from company ownership.

\section{Results}

Table 2 shows the results of two models, one with variables relating to the concentration, identity, and repeat-player hypotheses, and one with additional controls for market concentration and medium. Random intercepts are not shown, but are available on request. Three measures of fit are reported - the loglikelihood, the Akaike Information Criterion, and the Bayesian Information Criterion. Smaller values indicate better fit, leading us to prefer the more parsimonious model.

[Table 2 about here] 
These results confirm our hypotheses. The concentration hypothesis is confirmed: an increase in the effective number of owners - that is, a decrease in ownership concentration - is associated with a reduction in owner influence at the $5 \%$ level of statistical significance. The substantive magnitude of changes in the effective number of owners is slight across both models. A one-unit change in the effective number results in a decrease of between 0.167 and 0.194 in owner influence - roughly comparable to the difference between the average degree of ownership influence in Estonia (5.03) and the Czech Republic (5.22). Second, the identity hypothesis is also confirmed. There is likely to be significantly more owner influence in outlets that are owned by individuals and families than in outlets owned by companies. This effect is stronger for individuals than for families, perhaps reflecting coordination problems within families that are analogous to the coordination problems within the firm. The substantive magnitude of this effect is moderate. Each coefficient represents the change from $100 \%$ voting power (which means at least $50 \%$ of ownership) being held by a single company or a group of companies, to $100 \%$ voting power held by a single individual or a group of individuals, though obviously some changes in ownership structure involving individuals or companies acquiring smaller voting shares. Finally, the repeat-player hypothesis is also confirmed. Ownership groups which are national repeat-players are significantly more likely, and ownership groups which are international repeat-players significantly less likely, to exercise owner influence, compared to the reference category (a ownership 
group which possesses a single title or channel). Since these are dummy variables, the coefficients simply measure the effect of a change of type.

These findings are robust to the inclusion of controls for the degree of market concentration, and a dummy for whether or not the media outlet in question is a print or broadcast outlet. Contrary to expectations, owner influence is significantly higher in broadcast outlets.

\section{Conclusion}

In this article, I have demonstrated that higher levels of ownership concentration are associated with higher levels of owner influence over media outlets, and that owner is influence is greater where voting power within the company is concentrated in the hands of individuals and families rather than companies. I have also shown that ownership groups which own multiple titles on the national level only are more likely to exercise owner influence, whereas groups which spread their ownership across titles in different countries are less likely to exercise such influence.

What are the consequences of these findings for the broader literature? I suggest that my findings precede much of the literature on the critical political economy of the media. That literature generally agrees on two premises: corporatization, the claim that ownership of media companies by (multinational) corporations is increasingly common (Williams, 1981, 51; Golding and Murdock 1996, 64), and commodification, the claim that media 'products' are increasingly being treated as having no value other than exchange value, and are thus no different to 
products in other markets. It has either left unchallenged or ignored the standard assumption in micro-economics that corporations' behaviour can be described as if they were profit-maximizing, or, has argued that profit-maximizing behaviour is constrained on the margins by the need to maintain hegemony.

My argument is that corporations may not be very good even at maximizing profit, because corporatization in many instances is exaggerated (in my sample, nearly two-fifths of all ownership interests in print and broadcast media in Europe are individual or family ownership interests), and because individual owners have interests which cannot be reduced to profit (or shareholder return). I have therefore opened up an additional line of theoretically-informed criticism of private ownership of media companies. This criticism is important, because it shows that private ownership can fail on its own terms. Everything I have argued is entirely compatible with additional arguments that, since media 'products' do have a value which is distinct from their exchange value (i.e., their value in keeping us informed), private ownership by profit-maximizing companies is problematic.

Second, insofar as I open up lines of critique which are separate from those raised by the critical political economy of the media, I am pushing in the same direction as Hallin and Papathanassopoulos (2002), who argue that clientelism 
"gets us beyond a common dichotomy... between the liberal perspective, for which democratization of the media is purely a matter of the elimination of state interference, and the critical political economy perspective, which has focused on the control of media by private capital, but has until now not been very sophisticated in its analysis of variations in the relation of capital to the state, political parties and other institutions" (p. 184). Certainly the amenity potential of ownership is high in countries with a tradition of clientelism -- but as I have shown, that leads to only owner influence only through ownership concentration. The consequences of these findings for policy-makers are threefold. First, to the extent that policy-makers and regulators are involved in scrutiny of the acquisition of ownership shares in media outlets, they should exercise different levels of scrutiny depending on whether a proposed acquisition will take an ownership interest from an already-controlling share (i.e., greater than $50 \%+1$, which gives a Banzhaf score of 1) to a larger share, or whether instead the acquisition will increase the ownership interest's voting power compared to the status quo ex ante. Second, policy-makers and regulators interested in minimizing proprietorial influence have good reason to "pierce the corporate veil' and examine the ultimate owners behind ownership interests, because ultimate owners of different types differ in the propensity to exercise owner influence.

Third, insofar as minimizing owner influence is concerned, policy-makers should not erect higher barriers against ownership of media outlets by foreign operators (or more accurately, ownership groups which have other international 
titles but no other domestic title). These groups reduce owner influence, and the transition in Central and Eastern Europe from transnational to domestic ownership by well-connected individuals, identified by Stetka (2012), has only resulted in an increase in the extent to which any individual outlet's editorial line can be traced back to the interests of its owner.

The qualification in this last recommendation is important. Minimizing owner influence is rarely the only, or even the major, concern when regulating the media. Whilst owner influence of the kind we discuss here is one type of non-pecuniary benefit, or amenity potential, of media ownership, there are other non-pecuniary benefits which are more socially beneficial. To return to the example with which this article started, one important factor in Rupert Murdoch's successful acquisition of the Times and the Sunday Times was his desire, forcefully stated and by all accounts sincere, to maintain both papers as important and prestigious titles. The non-pecuniary benefit to Murdoch of maintaining both titles has led to considerable losses for News International (News Corporation's British subsidiary), which one estimate put at one million pounds weekly (Sabbagh, 2012). If access to a wide range of titles is valuable in democracies, this is one non-pecuniary benefit which we might wish to encourage by concentrated individual ownership. 


\section{References}

Bagdikian, B. H. (2004). The New Media Monopoly. Beacon Press, Boston.

Banzhaf, J. F. (1964). Weighted voting doesn't work: A mathematical analysis. Rutgers L. Rev., 19:317.

Berle, A. A. and Means, G. C. (1932). The modern corporation and private property. Macmillan, New York.

Besley, T. and Prat, A. (2006). Handcuffs for the grabbing hand? The role of the media in political accountability. American Economic Review, 96(3):720736.

Curran, J., Iyengar, S., Lund, A. B., and Salovaara-Moring, I. (2009). Media system, public knowledge and democracy: a comparative study. European Journal of Communication, 24(1):5-26.

DellaVigna, S. and Kennedy, A. (2011). Does media concentration lead to biased coverage? Evidence from movie reviews. Unpublished ms.

Demers, D. (1999). Global media: menace or messiah? Hampton Press, Cresskill, New Jersey.

Demers, D. and Merskin, D. (2000). Corporate news structure and the managerial revolution. The Journal of Media Economics, 13(2):103-121.

Demsetz, H. and Lehn, K. (1985). The structure of corporate ownership: Causes and consequences. The Journal of Political Economy, 93(6):1155-1177.

Djankov, S., Caralee, M., Nenova, T., and Shleifer, A. (2003). Who owns the media? Journal of Law and Economics, 46(2):341-381.

Evans, H. (1983). Good times, bad times. Weidenfeld and Nicolson, London. 
Freedman, D. (2013). Metrics, models and the meaning of media ownership. International Journal of Cultural Policy, forthcoming.

Gaziano, C. (1989). Chain newspaper homogeneity and Presidential endorsements. Journalism Quarterly, 66(4):836-845.

Hadenius, S. (1983). The rise and possible fall of the Swedish party press. Communication Research, 10(3):287-310.

Hallin, D.C., and Papathanassopoulos, S. (2002). Political clientelism and the media: southern Europe and Latin America in comparative perspective. Media, Culture and Society, 24(2):175-195.

Hamilton, J. (2004). All the news that's fit to sell: How the market transforms information into news. Princeton University Press, Princeton, NJ.

Hanitzsch, T. and Mellado, C. (2011). What shapes the news around the world? how journalists in eighteen countries perceive influences on their work. The International Journal of Press/Politics, 16(3):404-426.

Hanretty, C. (2010). Explaining the de facto independence of public broadcasters. British Journal of Political Science, 40(1):75-89.

Lacy, S. (1991). Effects of group ownership on daily newspaper content. Journal of media Economics, 4(1):35-47.

Leveson, B. (2011). An inquiry into the culture, practices, and ethics of the press. A report presented to Parliament pursuant to Section 26 of the Inquiries Act 2005.

Lukes, S. (1974). Power: A radical view. Macmillan, London. 
Mullainathan, S. and Shleifer, A. (2005). The market for news. American Economic Review, 95(4):1031-1053.

Murdock, G., and Golding, P. (1996). "Culture, Communications and Political Economy". In Curran J., and Gurevitch, M., Mass media and society (2nd ed.). London: Arnold.

Noam, E. (2009). Media ownership and concentration in America. Oxford University Press, New York.

Ofcom (2010). Report on public interest test on the proposed acquisition of British Sky Broadcasting Group plc by News Corporation. London. Available from:

http://stakeholders.ofcom.org.uk/binaries/consultation s/public-interest

-test-nov2010/statement/public-interest-test-

\section{report.pdf}

Popescu, M., Gosselin, T., and Santana Pereira, J. (2012). European media systems survey 2010. Available from: www.mediasystemsineurope.org.

Sabbagh, D. (2012). News corp's publishing arm to focus on losses at Times and Sunday Times. The Guardian.

Shawcross, W. (1997). Murdoch: the making of a media empire. Simon and Schuster, London.

Steenbergen, M. and Marks, G. (2007). Evaluating expert judgments. European Journal of Political Research, 46(3):347-366. 
Stetka, V. (2012). From multinationals to business tycoons : Media ownership and journalistic autonomy in Central and Eastern Europe. International Journal of Press/Politics, 17(4):433-456.

Stevenson, R. W. (1985). Murdoch is buying 50\% of Fox. New York Times, page A1.

Strömbäck, J. and Nord, L. W. (2006). Do politicians lead the tango? A study of the relationship between Swedish journalists and their political sources in the context of election campaigns. European Journal of Communication, 21(2):147-164.

Thomsen, S. and Pedersen, T. (2000). Ownership structure and economic performance in the largest European companies. Strategic Management Journal, 21(6):689-705.

Tunstall, J. and Palmer, M. (1991). Media moguls. Routledge, London.

Williams R. (1981). The Sociology of Culture. Chicago: University of Chicago Press.

Zaller, J. (1999). A theory of media politics. Unpublished ms. 
Figure 1: Ownership and voting power by $n$th shareholder

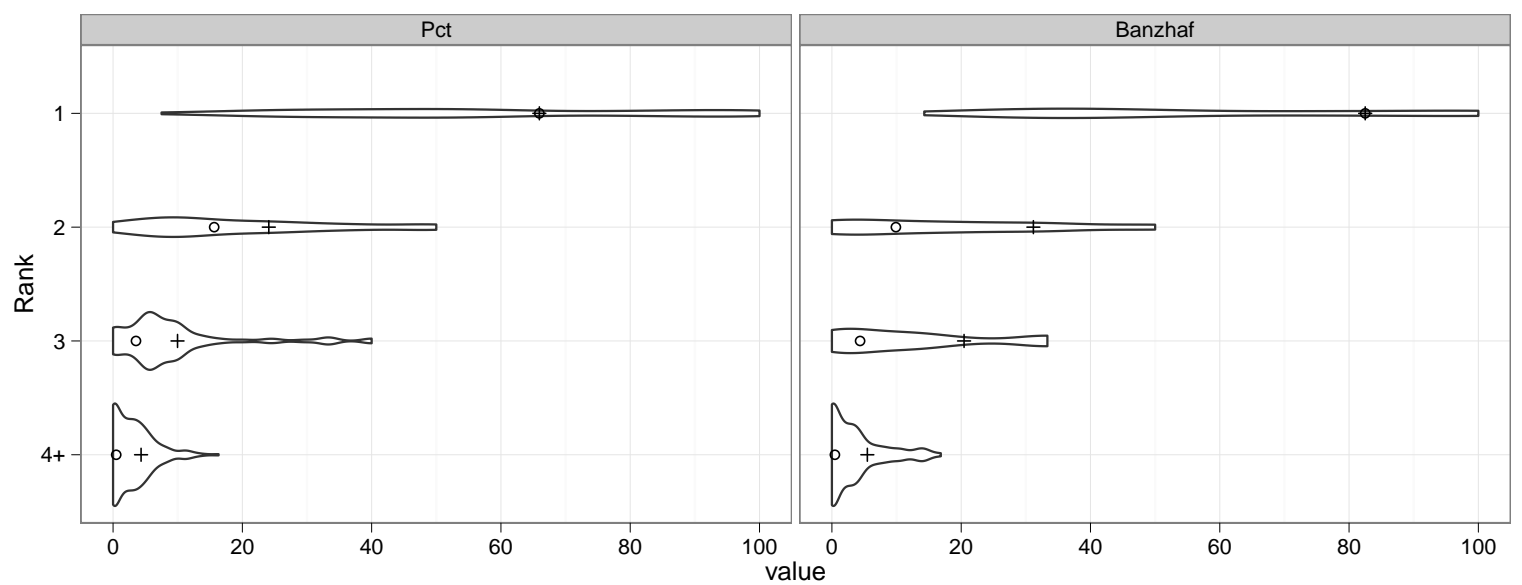

Note: Circle (०) gives the mean for all values; + gives the mean for non-zero values only. 
Table 1: Summary statistics

\begin{tabular}{lccccc}
\hline \hline Statistic & $\mathrm{N}$ & Mean & St. Dev. & Min & Max \\
\hline Owner influence & 211 & 6.111 & 2.127 & 1.200 & 10.000 \\
Effective number of owners & 211 & 1.622 & 1.213 & 1.000 & 7.669 \\
Total individual voting power & 211 & 0.263 & 0.415 & 0.000 & 1.000 \\
Total family voting power & 211 & 0.111 & 0.304 & 0.000 & 1.000 \\
Total foundation voting power & 211 & 0.050 & 0.214 & 0.000 & 1.000 \\
Total Party / state / ass'n voting power & 211 & 0.054 & 0.224 & 0.000 & 1.000 \\
Market concentration & 211 & $2,307.638$ & 696.420 & $1,187.723$ & $5,011.338$ \\
\hline
\end{tabular}


Table 2: Multilevel regression model

\begin{tabular}{|c|c|c|}
\hline & \multirow{2}{*}{\multicolumn{2}{|c|}{$\begin{array}{c}\text { Dependent variable: } \\
\text { Influence }\end{array}$}} \\
\hline & & \\
\hline & $(1)$ & $(2)$ \\
\hline (Intercept) & $\begin{array}{c}6.127^{* * *} \\
(0.342)\end{array}$ & $\begin{array}{c}6.013^{* * *} \\
(0.501)\end{array}$ \\
\hline Effective number owners & $\begin{array}{c}-0.246^{* * *} \\
(0.071)\end{array}$ & $\begin{array}{c}-0.226^{* * *} \\
(0.071)\end{array}$ \\
\hline Individual v. company & $\begin{array}{c}0.970^{* * *} \\
(0.237)\end{array}$ & $\begin{array}{c}1.089^{* * *} \\
(0.242)\end{array}$ \\
\hline Family v. company & $\begin{array}{l}0.557^{*} \\
(0.305)\end{array}$ & $\begin{array}{l}0.657^{* *} \\
(0.307)\end{array}$ \\
\hline Foundation v. company & $\begin{array}{l}-0.546 \\
(0.419)\end{array}$ & $\begin{array}{l}-0.304 \\
(0.434)\end{array}$ \\
\hline Party / state / ass'n v. company & $\begin{array}{l}1.012^{* *} \\
(0.440)\end{array}$ & $\begin{array}{l}0.851^{*} \\
(0.444)\end{array}$ \\
\hline National repeat-player & $\begin{array}{l}0.360^{*} \\
(0.212)\end{array}$ & $\begin{array}{l}0.377^{*} \\
(0.214)\end{array}$ \\
\hline International repeat-player only & $\begin{array}{c}-0.514^{* *} \\
(0.247)\end{array}$ & $\begin{array}{c}-0.730^{* * *} \\
\quad(0.266)\end{array}$ \\
\hline International, national repeat-player & $\begin{array}{l}-0.332 \\
(0.358)\end{array}$ & $\begin{array}{l}-0.518 \\
(0.366)\end{array}$ \\
\hline Market concentration & & $\begin{array}{c}-0.00004 \\
(0.0002)\end{array}$ \\
\hline Television outlet & & $\begin{array}{l}0.416^{* *} \\
(0.193)\end{array}$ \\
\hline Observations & 211 & 211 \\
\hline Log likelihood & -362.398 & -368.638 \\
\hline Akaike Inf. Crit. & 746.796 & 763.276 \\
\hline Bayesian Inf. Crit. & 783.666 & 806.850 \\
\hline
\end{tabular}

